\title{
DEVELOPMENT OF HULL-LESS BARLEY WITH ULTRA-LOW GLUTEN CONTENT VIA TARGET GENES COMBINATION. I. ISOLATION OF TRIPLE MUTANTS AND BLACK GRAINED GENOTYPES
}

\author{
O. I. Rybalka ${ }^{1}$, V. B. Katrii ${ }^{2}$, S. S. Polishchuk ${ }^{1}$, B. V. Morgun ${ }^{3}$ \\ ${ }^{1}$ National Centre of Seed and Cultivar Investigation «The Plant Breeding and Genetics Institute» NAAS \\ 3, Ovidiopolska Road, Odesa, Ukraine, 65036 \\ ${ }^{2}$ Institute of Plant Physiology and Genetics NAS of Ukraine \\ 31/17, Vasylkivska Str., Kyiv, Ukraine, 03022 \\ ${ }^{3}$ Institute of Cell Biology and Genetic Engineering NAS of Ukraine \\ 148, Akademika Zabolotnoho Str., Kyiv, Ukraine, 03143
}

E-mail: rybalkaalexander@gmail.com,katriy.vlad@gmail.com*,pol.sergey@ukr.net,molgen@icbge.org.ua

Received February 08, 2020 / Received March 04, 2021 / Accepted March 19, 2021

\begin{abstract}
Aim. The purpose of the research, presented in this paper, is to develop (as the first one in Ukraine) hull-less barley breeding material with ultra-low gluten, combining three hordein-deficient mutations, derived from Risø56, Risø1508, and R118, with black grain color as an indication of bioactive pigments content, enhancing the functional status of grain as a food product. Methods. We used electrophoretic analysis of proteins in polyacrylamide gel, DNA isolation by the CTAB method, polymerase chain reaction with DNA-markers, restriction analysis and electrophoretic separation of DNA in agarose gel. Results. The article presents the results of the first stage of combining target hordeindeficient mutations by binary crosses. The $\mathrm{F}_{2 / 3}$ and $\mathrm{F}_{3 / 4}$ populations were derived from binary crosses of Risø56 $\times$ Risø1508 (reciprocal Ris $\varnothing 1508 \times$ Risø56) and R118 $\times$ hull-less barley Achilles. The new PCR protocol was optimized. Markers B1hor, 3a5F and Dhor-m were selected to identify mutations in B, C and D hordeins. Conclusions. Several barley genotypes with one or two target hordein-deficient mutations and black grain color were isolated. The genotypes obtained will be used in a further backcrosses program, aimed at developing of a black hull-less barley variety with ultra-low gluten content.
\end{abstract}

Key words: Risø56, Risø1508, R118, gluten, molecular markers.

DOI: https://doi.org/10.15407/agrisp8.01.047

\section{INTRODUCTION}

In 2020, the global market value of gluten-free food products was estimated at USD 6.09 billion and is optimistically forecasted to increase with a further $7.7 \%$ annual growth up to USD 7.91 billion in 2026 (Gluten-Free Food Market Statistics, 2019). Therefore, breeding gluten-free varieties of food grain crops is undoubtedly an economically attractive topic of scientific research. Gluten is a protein complex, comprising about $80 \%$ of the total protein content in grain, which is notable for wheat (gliadins and glutenins), rye (secalins), triticale (gliadins, glutenins,

(C) O. I. RYBALKA, V. B. KATRII, S. S. POLISHCHUK, B. V. MORGUN, 2021 and secalins), barley (hordeins), and some varieties of oats (avenins). The specificity of gluten proteins, saturated with such amino acids as proline and glutamine, is their resistance to digestive enzymes of the gastrointestinal tract (Ravikumara $\mathrm{M}$ et al, 2007; Fritz RD, Chen Y, 2020; Scherf KA et al, 2018). As a result, peptides, not broken down into amino acids, or more specifically, epitopes (specific sequences of amino acids) of immunodominant peptides, can induce a pathological autoimmune disease in the human gastrointestinal system (Rosell C et al, 2014).

At least three important pathologies can be associated with consumption of gluten-containing food products (Kiewlicz J et al, 2020). The first one is an allergic reaction to gluten, which affects only $0.2-0.5 \%$ of the 
population, but it has some pronounced clinical implications, such as bloating, abdominal discomfort or pain, constipation and diarrhea. (Rosel C et al, 2014). The second one is an autoimmune disease, called celiac disease (CD), affecting $>0,5-0,9 \%$ of people worldwide. And the third one is recently identified pathological non-coeliac gluten sensitivity (NCGS), detected in $6 \%$ of the USA population (Igbinedion S et al, 2017), reaching to $10 \%$ in some other countries, such as Finland, Argentina, Brazil, Hungary (Aziz I et al, 2014; Golley S et al; 2015; Singh P et al, 2018). Despite being a common diagnosis, there is currently a paucity of information on NCGS, also in relation to the irritable bowel syndrome (IBS) which is carbohydrate based. Therefore it is essential now that individuals with gluten-related disorders are diagnosed accurately and managed appropriately (Igbinedion et al, 2017; Comino I et al, 2013; Catassi C et al, 2017).

To remove the toxicity of gluten proteins from food for people with coeliac and non- coeliac gluten sensitivity, some laboratories have been applying different methods of genetic modification of gluten proteins using gliadin-deficient mutants (Camerlengo $\mathrm{F}$ et al, 2017), transgenic RNA-interference (Gil-Humanes J et al, 2010; Gil-Humanes J et al, 2014), hordein-deficient mutant gene lys $3 a$ of barley (Moehs $C$ et al, 2019), and non-transgenic technology of genome editing CRISPR/ Cas9 (Sánchez-León S et al, 2017; Strygina K, Khlestkina EK, 2020).

Gluten-free barley (or rather barley with ultra-low gluten content) was developed by specialists of the Commonwealth Scientific and Industrial Organization (CSIRO) and the Grains Research and Development Corporation (GRDC) in Australia), via conventional breeding, including the combination of three hordeindeficient mutants (Tanner $\mathrm{G}$ et al, 2016). These developments lead to the first barley varieties with ultra-low gluten content $(\sim 5 \mathrm{ppm})$, namely Ohalo and Ohalo2, containing 10,000 times fewer hordeins as compared to conventional barley varieties. These barley varieties meet the requirements of the World Health Organization for gluten-free products $(<20 \mathrm{ppm})$, and have entered the global market of gluten-free food and non-alcoholic beverages under the trademark Kebari ${ }^{\circledR}$ (www.csiro.au).

It took 14 years to develop the above-mentioned barley varieties Ohalo and Ohalo2. Being protected with Australian patents and the trademark Kebari ${ }^{\circledR}$ (hulled and hull-less barley), the ultra-low gluten varieties are licensed, and it is till now impossible to freely procure them for commercial application.
Taking into consideration the studies of Tanner et al, (2013, 2014, 2016), we set a task of developing genetically, Ukrainian based, barley material with ultra-low content of gluten via traditional breeding using molecular markers, combining the mutants also used by Tanner et al, $(2014,2016)$ in one genotype: three hordein-deficient mutations of collection induced mutant barley lines Risø1508 and Risø56 form Carlsberg Research Laboratory, Valby, Denmark, and spontaneous D-hordein-deficient mutant R118 from Ethiopia, which is the most suitable candidate for the role of a mutation donor. This article presents the results of this stage of our research, namely, the combination of two main hordein-deficient mutations in one genotype and transferring the D-hordein-deficient mutation R118 onto the adaptive basis of a commercial variety of hull-free barley, suitable for growing in Ukrainian and similar climatic zones.

\section{MATERIALS AND METHODS}

The original grain of hordein-deficient barley mutants Risø1508 (containing the mutation M1508) and Risø56 (with the mutation M56) (both - two-row, chaffy, spring barley) was obtained from the national collection of the USA (USDA, the National Plant Germplasm System). The original grain of spontaneous D-hordein-deficient mutant R118 (six-row, hull-free, spring, black grain) was received from the Germplasm Resource Unit, John Innes Centre, UK. Mutant R118 of African origin, obtained from The John Innes Centre Public Collections, Norwich, (Tanner G et al, 2015) is satisfactorily adapted to drought conditions of southern Ukraine and forms well-filled grain. Achilles is a two-row hull-free barley variety, bred by Plant Breeding and Genetics Institute, National Center of Seed and Cultivars Investigation, NAAS of Ukraine in 2014, greatly adapted to Odesa region local climatic conditions, drought-tolerant and lodging-resistant, which was used in the crossing with mutant R118.

Reciprocal hybrids $\mathrm{F}_{1}$ and $\mathrm{F}_{1 / 2}\left(\mathrm{~F}_{1}\right.$ plants with $\mathrm{F}_{2}$ grain) after crossings Risø1508 $\times$ Risø56, Risø56 $\times$ Risø1508, and Achilles $\times$ R118 were obtained the same year in vegetation pots). The populations $\mathrm{F}_{2 / 3}$ and $\mathrm{F}_{3 / 4}$ from these crossings were cultivated under field conditions without any selection. Individual spikes of plants with black grain were selected by their best agronomic traits in the population $\mathrm{F}_{3 / 4}$ Achilles $\times \mathrm{R} 118$.

The electrophoresis of hordeins from each grain was done in two variants: (Rybalka $\mathrm{O}$ et al, 2019) in polyacrylamide gel (PAAG) with acid buffer, pH 3.1 (APAGE), and in denaturating polyacrylamide gel with 
sodium dodecylsulfate (SDS-PAGE) in the classic buffer system (Laemmli $U$ et al, 1970) with $\mathrm{pH} 6.8$ and $\mathrm{pH} 8.8$ in the concentrating and separating (shortened to $80 \mathrm{~mm}$ ) gels respectively, at $100 \mathrm{~V}$ voltage. The extraction of hordeins from individual barley grains for electrophoresis in acid gel ( $\mathrm{pH} 3.1$ ) was done with $70 \%$ ethanol (v/v), and hordeins for mini-SDS electrophoresis were extracted with the extraction buffer solution, pH 6.8. A commercial hull-less barley cultivar Achilles listed in Ukraine was used as the variety-standard along with a molecular weight marker to recognize hordein proteins.

Simultaneously with the electrophoretic analysis of hordeins, mutant genes in the populations were identified by PCR. Total DNA was isolated from barley grain by the standard CTAB method (with hexadecyltrimethylammonium bromide) (Lipp M et al, 1999) and stored in the freezer at $-20^{\circ} \mathrm{C}$ - until the end of the experiment. The PCR with specific primers to determine mutation M56, associated with altered accumulation of B-hordeins, was conducted according to the protocol of Tanner $\mathrm{G}$ et al (2014). The nucleotide sequences of DNAmarker B1hor were as follows: 5'B1hor 5'-CAA CAA TGA AGA CCT TCC TC-3' and 3'B1hor 5'-TCG CAG GAT CCT GTA CAA CG-3' (synthesized by Metabion, Germany). Reaction mixture for PCR included: $0.25 \mu \mathrm{M}$ each of specific primer, $2 \mu$ of $10 \times$ Reaction Buffer B (Solis BioDyne), $2 \mathrm{mM}$ final concentration of $\mathrm{MgCl}_{2}$ (Solis BioDyne), $0.2 \mathrm{mM}$ final concentration of deoxyribonucleotide-3-phosphate (Thermo Fisher Scientific), 0.5 units of activity FIREPol DNA Polymerase (Solis BioDyne), 100 ng total DNA anddeionized Milli-Q water (Merck Millipore) to a final volume of $20 \mu \mathrm{l}$. GeneRuler DNA Ladder Mix (Thermo Fisher Scientific, USA) was used as molecular weight marker. The amplification program -1 cycle at $94{ }^{\circ} \mathrm{C}-4 \mathrm{~min}$; 35 cycles at $94{ }^{\circ} \mathrm{C}-30 \mathrm{~s}, 56{ }^{\circ} \mathrm{C}-30 \mathrm{~s}, 72{ }^{\circ} \mathrm{C}-1 \mathrm{~min}$; 1 cycle at $72{ }^{\circ} \mathrm{C}-5 \mathrm{~min}, 22{ }^{\circ} \mathrm{C}-1 \mathrm{~min}$, was initiated in the thermocycler, Eppendorf Mastercycler ${ }^{\circledR}$ gradient (Germany). The reaction products were separated by DNA electrophoresis in $1.2 \%$ agarose gel. The length of expected amplicons was $800 \mathrm{bp}$ for wild type (Achilles), and the presence of mutation M56 was identified by the absence of this amplicon.

The detection of mutation M1508, associated with impaired biosynthesis of C-hordeins, involved specific DNA amplification with its further hydrolysis using endonuclease BseYI (New England Biolabs, UK) by the functional principle of allele-specific cleaved amplified polymorphic sequences (CAPSs) of a DNA-marker
(Moehs et al, 2019). For PCR, we used at the portal of the National Center for Biotechnology Information (NCBI) of the National Institutes of Health, USA www. ncbi.nlm.nih.gov/tools/primer-blast/. The sequences of primers were as follows: 3a5F 5'-CCT CGG TGC AAG TCT GGT AA-3' and 3a5R 5'-AAA CGT CGG GAG GAC GTT AG-3'.

The amplification program was used as follows: 1 cycle at $94{ }^{\circ} \mathrm{C}-4 \mathrm{~min} ; 8$ cycles at $94{ }^{\circ} \mathrm{C}-30 \mathrm{~s}, 65^{\circ} \mathrm{C}-$ $30 \mathrm{~s}, 72{ }^{\circ} \mathrm{C}-45 \mathrm{~s} ; 30$ cycles at $94{ }^{\circ} \mathrm{C}-30 \mathrm{~s}, 57{ }^{\circ} \mathrm{C}-$ $30 \mathrm{~s}, 72{ }^{\circ} \mathrm{C}-40 \mathrm{~s} ; 1$ cycle at $72{ }^{\circ} \mathrm{C}-5 \mathrm{~min}, 22{ }^{\circ} \mathrm{C}-$ $1 \mathrm{~min}$. Reaction mixture for PCR included: $0.25 \mu \mathrm{M}$ each of specific primer, $2 \mu \mathrm{l}$ of buffer for PCR 10× Reaction Buffer B (Solis BioDyne), 2 mM final concentration of $\mathrm{MgCl}_{2}$ (Solis BioDyne), $0.2 \mathrm{mM}$ final concentration of deoxyribonucleotide-3-phosphate (Thermo Fisher Scientific), 0.5 units of activity FIREPol DNA Polymerase (Solis BioDyne), 100 ng total DNA and deionized Milli-Q water (Merck Millipore) to a final volume of $20 \mu \mathrm{l}$. The Risø1508 mutant was used as positive control, reaction mix without DNA was used as negative control and GeneRuler DNA Ladder Mix (Thermo Fisher Scientific, USA) was used as molecular weight marker. The separation of amplicons was conducted by DNA electrophoresis in $1.2 \%$ agarose gel in lithium borate buffer with $0.05 \mu \mathrm{g} / \mathrm{ml}$ ethidium bromide at the voltage of $5 \mathrm{~V} / \mathrm{cm}$ for $40 \mathrm{~min}$. The length of the expected amplicons was equal to 270 bp. Mutation M1508 was identified by the restriction analysis with type II endonuclease BseYI (Table 1) according to Moehs et al, (2019). The nucleotide sequence of the recognition site, located at the amplified DNA fragment, was as follows:

\section{$\mathrm{C} * \mathrm{CCAGC}$ \\ GGGTC*G}

The reaction mixture for DNA hydrolysis was comprised of $5 \mu 1$ amplified DNA (crude PCR), $12.8 \mu 1$ deionized water Milli-Q ${ }^{\circledR}$ (Merck Millipore, Germany), 2 $\mu 110 \times$ reaction buffer and 2 enzyme units. The incubation was conducted at $37^{\circ} \mathrm{C}$ for $3 \mathrm{~h}$. DNA separation and staining were similar to that used for crude DNA described above. The presence of mutation M1508 was identified by the uncleaved amplicon of 270 bp after the restriction digestion with endonuclease BseYI of previously amplified samples.

The detection of mutation R118 in terms of biosynthesis of barley D-hordeins was conducted by PCR with specific primers according to the protocol of Tanner G et al (RU2518241C2, Tanner G et al, 2014). The nucleotide sequences of marker Dhor-m were 
RYBALKA et al.

5'Dhor-m 5'-GGC AAT ACG AGC AGC AAA C-3' and 3'Dhor-m 5'-CCT CTG TCC TGG TTG TTG TC$3^{\prime}$. Reaction mixture for PCR included: $0.25 \mu \mathrm{M}$ each of specific primer, $2 \mu \mathrm{l}$ of buffer for PCR $10 \times$ Reaction Buffer B (Solis BioDyne), $2 \mathrm{mM}$ final concentration of $\mathrm{MgCl}_{2}$ (Solis BioDyne), $0.2 \mathrm{mM}$ final concentration of deoxyribonucleotide-3-phosphate (Thermo Fisher Scientific), 0.5 units of activity FIREPol DNA Polymerase (Solis BioDyne), 100 ng total DNA filled with deionized Milli-Q water (Merck Millipore) to a final volume of $20 \mu \mathrm{l}$. The R118 mutant was used as a positive control, reaction without DNA was used as negative control and GeneRuler DNA Ladder Mix (Thermo Fisher Scientific, USA) was used as molecular weight marker. The amplification program was used as follows: 1 cycle at $94{ }^{\circ} \mathrm{C}-4$ min; 35 cycles at $94{ }^{\circ} \mathrm{C}-30 \mathrm{~s}, 56{ }^{\circ} \mathrm{C}-30 \mathrm{~s}, 72{ }^{\circ} \mathrm{C}-1 \min 72{ }^{\circ} \mathrm{C}-5 \mathrm{~min}$, $22{ }^{\circ} \mathrm{C}-1 \mathrm{~min}$. The separation of amplicons was conducted by DNA electrophoresis in $1.2 \%$ agarose gel in lithium borate buffer with $0.05 \mu \mathrm{g} / \mathrm{ml}$ ethidium bromide at the voltage of $5 \mathrm{~V} / \mathrm{cm}$ for $40 \mathrm{~min}$. The length of the expected amplicons was equal $-300 \mathrm{bp}$. Mutation R118 was identified by the restriction analysis with type II endonuclease KpnI (Thermo Fisher Scientific, USA). The nucleotide sequence of the recognition site, located at the amplified DNA fragment, was as follows:

$$
\begin{aligned}
& \text { 5'GGTAC }{ }^{\mathbf{V}} \text { C3 }^{\prime} \\
& \text { 3'C } \text { CATGG5' }^{\prime}
\end{aligned}
$$

The reaction mixture for DNA hydrolysis was comprised of $5 \mu 1$ amplified DNA (crude PCR), $12.8 \mu 1$ de- ionized water Milli-Q ${ }^{\circledR}$ (Merck Millipore, Germany), 2 $\mu 110 \times$ reaction buffer and 2 enzyme units. The incubation was conducted at $37{ }^{\circ} \mathrm{C}$ for $3 \mathrm{~h}$. DNA separation and staining were similar to that used for crude DNA described above. The presence of mutation R118 was identified by the uncleaved amplicon of $300 \mathrm{bp}$ after the restriction digestion with endonuclease KpnI of previously amplified samples.

\section{RESULTS}

The mutant plants Risø1508 and Risø56 are rather primitive genotypes by agronomic traits, form grain with reduced endosperm, and are not drought-resistant (Fig. 1).

Therefore, practical implementation of combining target genes into one genotype was done via the following consecutive steps: 1) obtaining double-mutant genotypes from the crossing of chaffy mutants Risø1508 $\times$ Risø56 and selection of those with the best agronomic traits; 2) selection of agronomically more valuable D-hordein-deficient genotypes with black grain in the population from crossing Achilles $\times$ R118; 3) selection of agronomically satisfactory triple-mutant (Risø1508+Risø56+R118) genotypes with black grain.

Results of the double electrophoretic detection of mutants gave the following results.

Fig. 2 presents the electrophoregram of SDS-PAGE electrophoretic separation of B-, C-, and D-hordeins of

Table 1. The description of a change in locus lys 3 , controlling the biosynthesis of B- and C-hordeins, and the approach to its

\begin{tabular}{|c|c|c|}
\hline Phenotype & $\begin{array}{l}\text { Wild type, Achilles variety, } \\
\text { comprehensive synthesis of hordeins }\end{array}$ & $\begin{array}{l}\text { Mutant Risø1508 with recessive } \\
\text { allele lys } 3 a \text {, decreased content } \\
\text { of B- and C-hordeins }\end{array}$ \\
\hline Aminoacid sequence & ...NYSMSQ QPRY ... & ...NYSMSLPRY ... \\
\hline Altered aminoacid in position 58 & Gln, Q, glutamine & Leu, L, leucine \\
\hline $\begin{array}{l}\text { Possible triplets of standard genetic } \\
\text { code }\end{array}$ & $\begin{array}{l}\text { CAA } \\
\text { C } \underline{A} G\end{array}$ & $\begin{array}{l}\text { UUA } \\
\text { UUG } \\
\text { CUU } \\
\text { CUC } \\
\text { CUA } \\
\text { CUGG }\end{array}$ \\
\hline Altered nucleotide in position 173 & \multicolumn{2}{|c|}{$\mathrm{A} \rightarrow \mathrm{T}$} \\
\hline Recognition site with incision point & 5'C $\boldsymbol{\nabla C C} \underline{\mathrm{A} G C} 3^{\prime}$ & 5'C $\nabla \mathrm{CC} \mathbf{T G C} 3{ }^{\prime}$ \\
\hline $\begin{array}{l}\text { Hydrolysis with restrictase BseYI } \\
\text { (GsaI, PspFI), size of fragments }\end{array}$ & $\begin{array}{c}+ \\
56+214 b p\end{array}$ & $\stackrel{-}{270 \mathrm{bp}}$ \\
\hline
\end{tabular}
recognition 


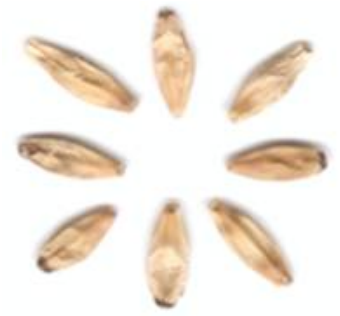

Risø56

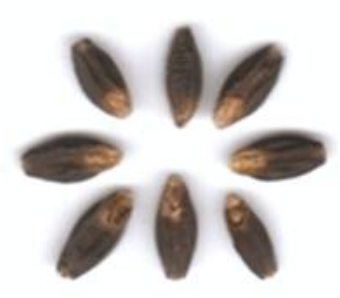

R118

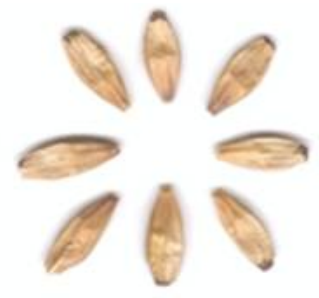

Risø1508

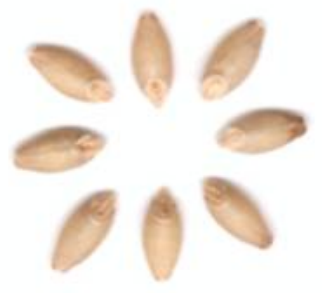

Achilles

Fig. 1. The external appearance of grain of genotypes, used in the study

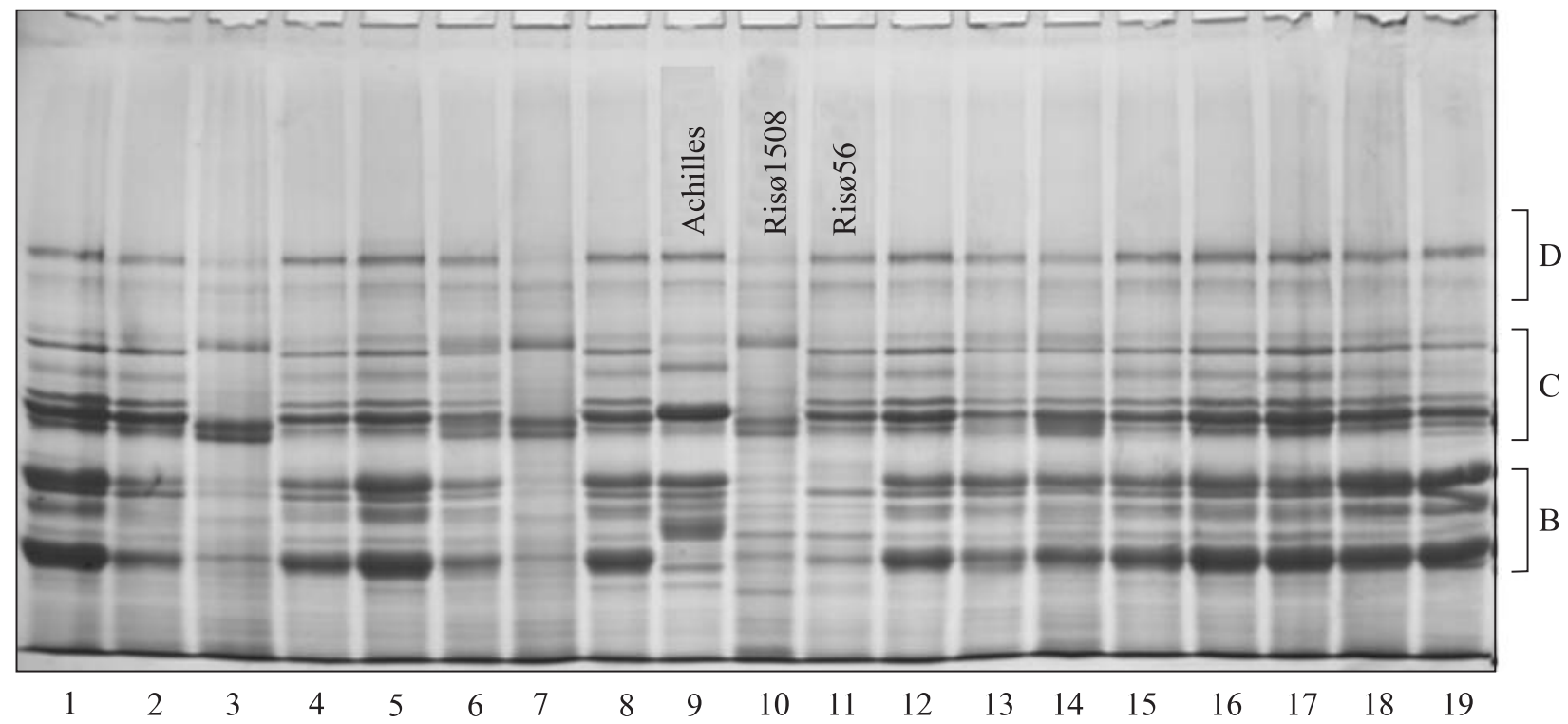

Fig. 2. SDS-PAGE electrophoregram of separating barley hordeins: lane 9 -Achilles variety; 10 - mutant Risø1508; 11 - mutant Risø56; lanes 1-8, 12-19 - genotypes of populations $\mathrm{F}_{3 / 4}$ from crossing Risø1508 × Risø56 (Risø56 × Risø1508); lanes 3 and 7 - genotypes from the population, containing allele lys $3 a$

the initial barley samples: hull-free variety Achilles, mutants Risø1508 and Risø56, and genotypes of population $\mathrm{F}_{3 / 4}$ from crossing Risø1508 × Risø56 (Risø56 × $\times$ Risø1508). It is evident that mutant Risø1508 practically does not have B- and D-hordeins and reduced C-hordeins. The biosynthesis of B-hordeins is practically blocked completely in mutant Risø56.

Fig. 3 presents A-PAGE electrophoregram of separating barley $\mathrm{B}$ - and $\mathrm{C}$-hordeins. Unfortunately, Dhordeins were not visualized by A-PAGE method. It demonstrated that the efficiency of separating barley hordeins in SDS-PAGE system was higher than in A-PAGE system. Both SDS-PAGE and A-PAGE systems clearly detect practically complete absence of B- and C- hordeins in Risø1508, and as for mutant Risø56 - almost complete depression of biosynthesis of B-hordeins.

The genotypes of the populations $\mathrm{F}_{2 / 3}$ and $\mathrm{F}_{3 / 4}$ are also clearly identified by both SDS-PAGE and A-PAGE systems by the trait of presence/absence of B- and Chordeins and the possibility of separating genotypes with double mutation from Risø1508 and Risø56 from the population (Fig. 3, lanes 2, 7; Fig. 4, lanes 1, 3).

However, according to the data of electrophoretic analysis of hordeins, the genotypes with assumed presence of a double mutation are almost identical in their spectra to Risø1508 and difficult to identify. Only the absence of several minor electrophoretic components, notable for Risø56, demonstrates a double mutation in the genotype.

Thus, to have a more reliable identification of all three mutations Risø1508, Risø56, and R118, it was necessary to process the system of detecting mutations by PCR marking.

The visualization of the amplification of investigated genotypes is presented in Fig. 4. After the amplification with marker B1hor, the genotypes of wild type Achilles variety and mutant Risø1508 (Fig. 4, lanes 2, 4) give 


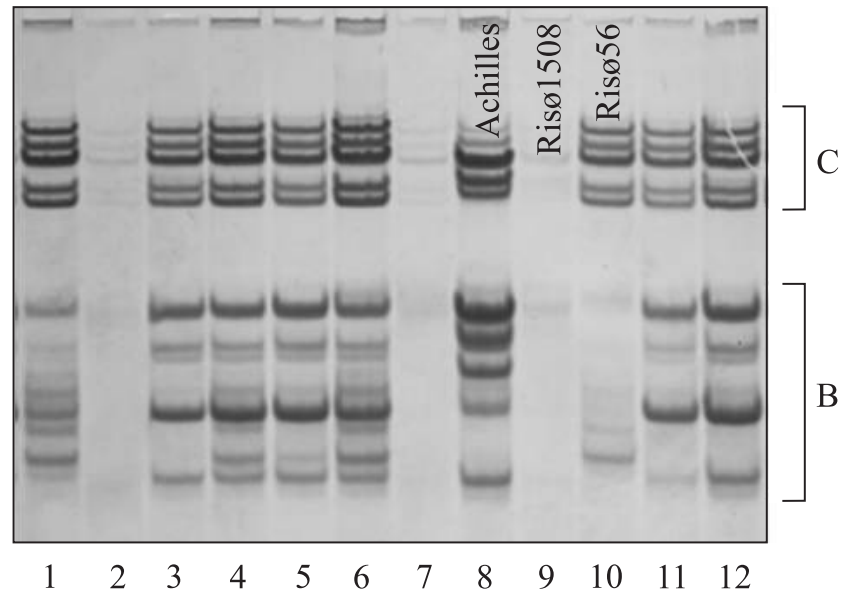

Fig. 3. A-PAGE electrophoregram of separating barley B- and C-hordeins. Lane 8 - Achilles variety; 9 - mutant Risø1508; 10 - mutant Risø56; lanes 1-7, 11, 12 - genotypes of populations $\mathrm{F}_{3 / 4}$ from crossing Risø1508 × Risø56 (Risø56 $\times$ Risø1508); lanes 2 and 7 -genotypes from the population, containing allele lys $3 a$

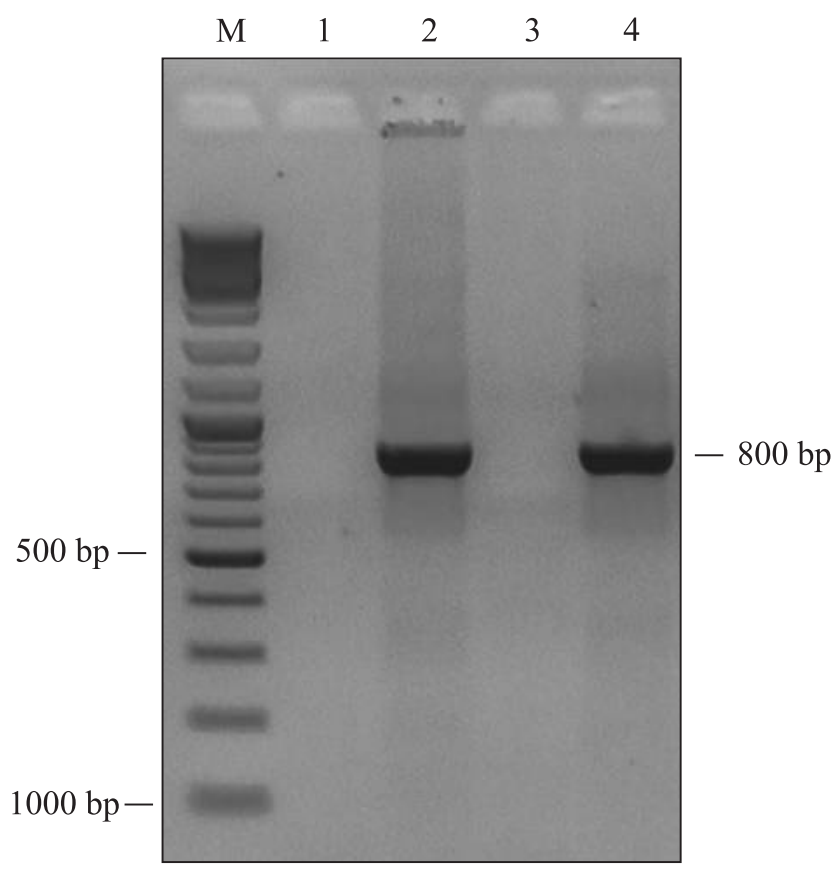

Fig. 4. The result of visualizing mutation M56 by DNAmarker B1hor. $\mathrm{M}$ - molecular mass marker GeneRuler DNA Ladder Mix (Thermo Fisher Scientific, USA), lane $1-$ mutant Risø56; 2 - Achilles variety, wild type; 3 - genotype from the population, containing mutation M56; 4 - mutant Risø1508

the amplicon of $800 \mathrm{bp}$, while the same amplicon is absent in the mutant genotype - line Risø56 and the selected genotype from the population, which was found to contain mutation M56. The new PCR procedure and primers we developed to detect mutation M56 in the
B-hordein locus Hor2 overcomes the difficulties in SDS-PAGE and A-PAGE detection of target genotypes with a double mutation (Fig. 4, lanes 1 and 3).

The PCR detection of recessive mutant allele $l y$ $s 3 a$, or so-called mutation M1508, carried by mutant Risø1508 requires DNA digestion because it is a point mutation of $\mathrm{A} \rightarrow \mathrm{T}$ type with the replacement of only one nucleotide (Moehs, et al, 2019). In the first stage of PCR amplification with DNA-marker 3a5, we obtained the amplicon of $270 \mathrm{bp}$, which was the same both for mutant Risø1508 and the wild type, Achilles variety (Fig. 5, a). Then mutation M1508 was identified by hydrolysis of the amplified fragment of $270 \mathrm{bp}$ using restrictase BseYI. After the hydrolysis, the mutant sample of Risø1508 produced the same unchanged amplicon of $270 \mathrm{bp}$, while the samples of the wild type gave two fragments of $214 \mathrm{bp}$ and 56 bp (Fig. 5, $b$ ).

The identification of mutation R118 in locus Hor3, encoding the biosynthesis of D-hordeins, also involved restriction enzyme analysis using KpnI. The mutation R118 in genotypes of population $\mathrm{F}_{2 / 3}$ and $\mathrm{F}_{3 / 4}$ was identified by the presence of the amplicon of $300 \mathrm{bp}$ (Fig. 6). In our experiments we tested two individual grains from each individually selected 710 spikes from populations $\mathrm{F}_{2 / 3}$ and $\mathrm{F}_{3 / 4}$.

We wanted to isolate a maximum number of double mutants M1508+M56 from the investigated populations for further crossing. While selecting in populations $\mathrm{F}_{2 / 3}$ and $\mathrm{F}_{3 / 4}$, we considered the data of Doll $\mathrm{H}$., and Oram R. (1989), who studied 75 populations from the crossings involving Risø1508, and demonstrated a considerable decrease (deviation from the Mendelian) in the frequency of genotypes with gene lys $3 a$ as compared to the theoretically expected ones in some cases. During selection, we paid attention to specific morphological specificities of spikes, containing the grain with reduced endosperm.

A total of 710 individual spikes were selected from two populations: $160 \mathrm{~F}_{2}$ spikes and $550 \mathrm{~F}_{3}$ spikes were analyzed for the presence of target mutations. The data of the electrophoretic analysis of hordeins from both populations were used to select 63 genotypes with the electrophoretic spectrum of Risø1508 type hordeins from allele lys $3 a$. Mutation lys $3 a$ (also called mutation M1508) blocks the biosynthesis of B-hordeins, as does mutation M56 and therefore has the same phenotypic manifestation as M56. It means that in genotypes of the population with gene lys $3 a$, the effect of blocking B-hordeins by mutation Risø56 was masked by the mutation lys $3 a$. There fore populations with gene 

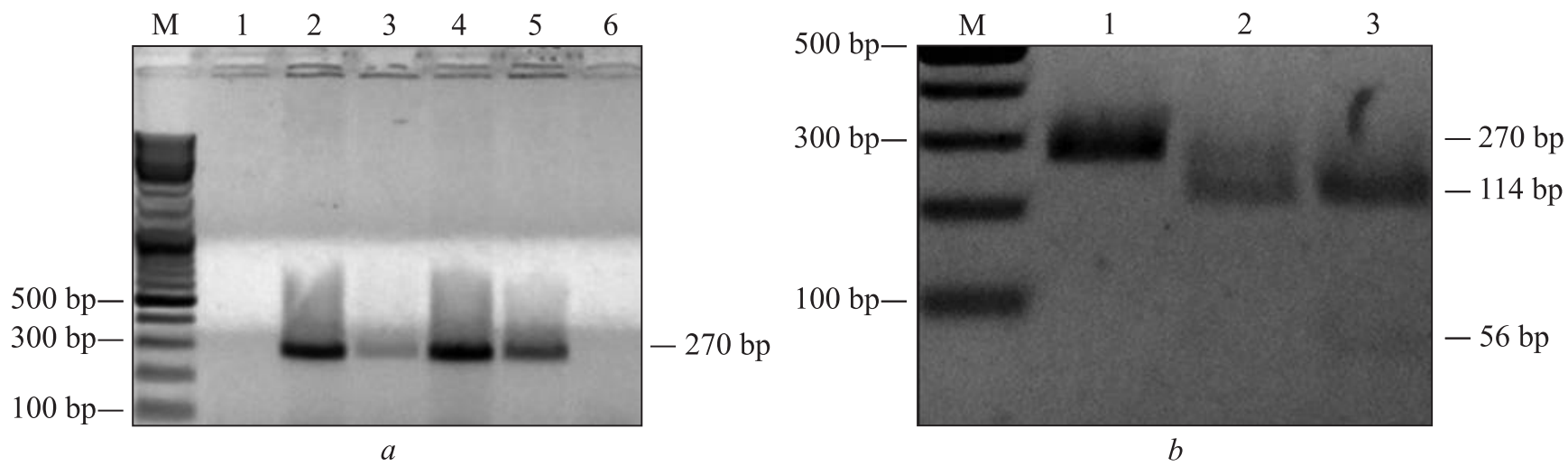

Fig. 5. The detection of mutation M1508, i.e. recessive allele lys $3 a$ in the gene, encoding Barley Prolamin-box Binding Factor (BPBF). $a$ - the visualization of PCR products with DNA-marker 3a5, selected by us. M - molecular mass marker DNA Ladder Mix; lines 1, 6 - K0 control without DNA; 2 - line Risø1508; lines 3, 4, 5 - wild type, Achilles variety. $b$ - the result of cleaving the amplified DNA samples of $270 \mathrm{bp}$ with endonuclease BseYI. M - molecular mass marker DNA Ladder Mix; line 1 - line Risø1508; lines 2 and 3 - wild type, Achilles variety

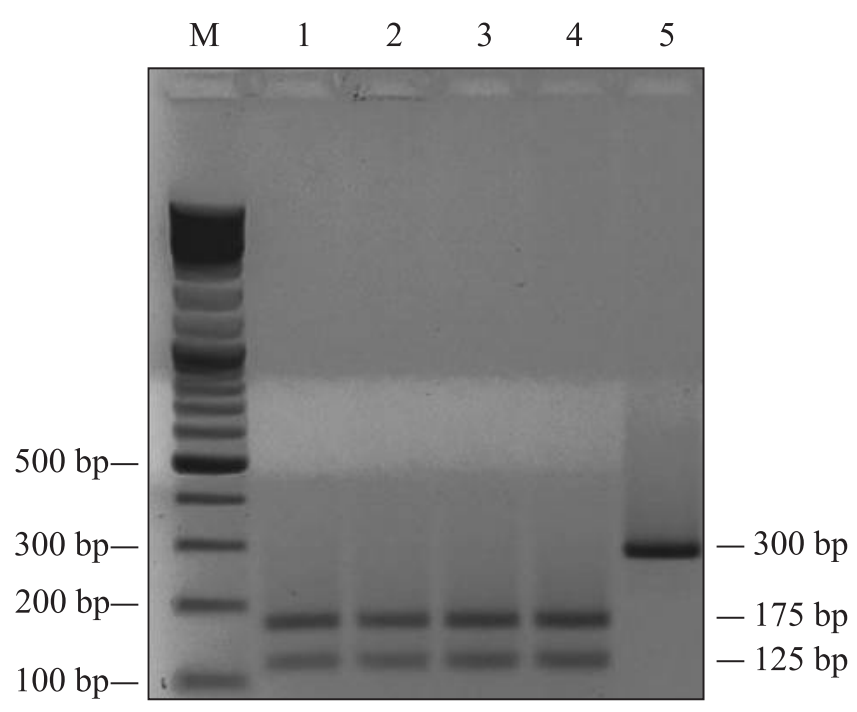

Fig. 6. The result of visualizing the restriction analysis of the amplified DNA samples from mutant R118 using DNAmarker Dhor-m. M - molecular mass marker DNA Ladder Mix; lanes 1, 2 - Achilles variety, wild type; 3 - mutant Risø1508; 4 - mutant Risø56; 5 - mutant R118

lys $3 a$ carry a double mutation, which can only be identified by PCR. A simultaneous PCR testing of genotypes from the population with gene lys $3 a$ confirmed a double target mutation M1508+M56 only in 12 out of the 63 genotypes with mutation lys $3 a$, selected by electrophoresis. These 12 spikes will be used for further crossing.

A total of 275 agronomically valuable spikes of a hull-free genotype with black grain were selected in a population $\mathrm{F}_{3 / 4}$ from crossing D-hordein-deficient mutant R118 $\times$ Achilles. Only 5 out of 88 (5.68 \%) genotypes, investigated by electrophoresis of hordeins and
PCR testing, were found to be D-hordein-deficient. A low frequency of isolating mutation M56 in locus Hor 2, responsible for controlling the biosynthesis of B-hordeins, was also registered. Only 8 out of 102 (7.84 \%) genotypes, which underwent PCR testing, were found to be B-hordein-deficient.

\section{DISCUSSION}

The final objective of our work is to breed a nonpatented, hull-less barley variety with ultra-low gluten content via classical target genes combination using a suitable Ukrainian barley variety as basis, for the benefit of Ukrainian and possibly worldwide food production. The most significant part of the study, presented here, is obtaining a triple mutant genotype of food hullfree barley with ultra-low content of such gluten proteins as hordeins, containing all three mutations from genetic sources Risø1508, Risø56, and R118, which almost block the biosynthesis of barley hordeins and furthermore with black grain, originating from mutant R118, possessing bioactive pigments with high antioxidant activity (Schalk K et al, 2017).

The theoretical foundation of our study is largely based on the insights in the barley-gluten-hordein associations/genetics as developed and elaborated by Tanner, 2013, 2014, 2016: gluten proteins of barley, hordeins, comprise $35-55 \%$ from the total content of nitrogen in grain. They consist of 4 groups of polypeptides (Table 2). The main quantitative share of gluten proteins in barley is comprised of hordeins B and C. Hordeins $\mathrm{D}$ and $\gamma$-hordeins are present in grain in minor quantities (Shewry P, 1993; Kreis M et al, 1983).

The biosynthesis of the main fraction of hordeins, namely, the family of hordeins $\mathrm{B}$ and $\mathrm{C}$, is ensured by 
RYBALKA et al.

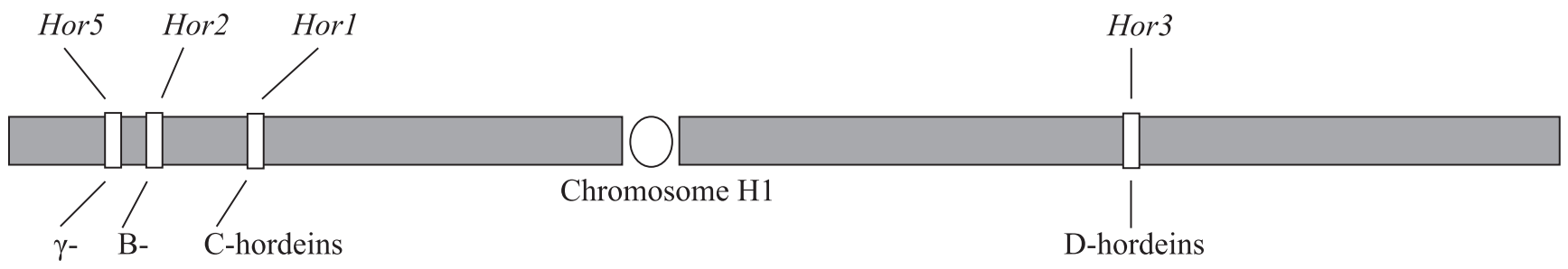

Fig. 7. The location of target hordein-encoding loci on the genetic map of chromosome $1 \mathrm{H}$ of barley (Tanner $\mathrm{G}$ et al, 2014)

13 and 20-30 genes, respectively. The biosynthesis of B-hordeins is conditioned by locus Hor2 in a short arm of the chromosome $1 \mathrm{H}$ (Fig. 7). The high-lysine barley mutant Risø56 contains a genome deletion of $8.5 \times$ $\times 10^{3} \mathrm{bp}$, induced by $\gamma$-rays, which carries a B-hordein locus. Due to the deletion, B-hordeins are absent from this mutant (Shewry P et al, 1985).

Locus Horl encodes C-hordeins in a short arm of chromosome 1H. Barley mutant Risø1508, induced by ethyl methanesulfonate, contains a recessive allele lys $3 a$ on chromosome $7 \mathrm{H}$. This gene encodes the transcription factor with altered demethylase activity, required for the expression of C-hordeins. Due to mutation lys $3 a$, C-hordeins are not synthesized in mutant Risø1508, and the synthesis of B- and D-hordeins is depressed. The loci for B- and C-hordeins are closely linked at the distance of $12.6 \mathrm{cM}$ of the recombination and represent a DNA area of 10 million bp. Hordein D is a polypeptide of $105 \mathrm{kDa}$, encoded by locus Hor3 (Tanner $\mathrm{G}$ et al, 2016). A spontaneous mutant R118 from The John Innes Centre Public Collections, Norwich, carries a mutation, blocking the biosynthesis of D-hordeins (Brennan C et al, 1998).

The family of $\gamma$-hordeins ( $\gamma-1$ and $\gamma-3)$ of barley is encoded by two genes in locus Hor 5 on the short arm of chromosome $1 \mathrm{H}$ : three $\gamma$-hordeins 1, 2, and 3 of about 45,40 , and $38 \mathrm{kDa}$ respectively, where $\gamma-2$ protein comes from $\gamma-1$ protein via post-translational modification with the loss of 30 amino acids (Table 2). $\gamma$-Hordein locus Hor 5 is closely linked to locus Hor 2 for B-hordeins at the distance of mere $0.2 \mathrm{cM}$ (Shewry P, 1993).
Thus, to obtain the genotypes of black hull-free barley with ultra-low content of gluten, which would have almost no hordeins, we should combine all three independent hordein-deficient mutations in one genotype and add nud gene here (a trait of being hull-free), which is located on chromosome 7HL, and a gene of black color of pericarp Blp, located on the long arm of chromosome 1HL.

Noteworthy is the presence of B-hordeins in the genotypes of the populations we have presently under investigation, while B-hordeins are absent from both initial components of crossing mutants Risø1508 and Risø56. This phenomenon may be explained by the fact that both mutations in Risø1508 and Risø56 are of recessive nature, blocking the biosynthesis of B-hordeins by "recessive epistasis" type. The alternative wild type allele for each mutation apparently restores the biosynthesis of B-hordeins (Sozinov A et al, 1976), which we actually observed during the electrophoretic analysis of hordeins in our populations (Fig. 2 and 3).

The laboratory protocol for PCR detection of mutation M1508, developed by us, efficiently supplements the electrophoretic analysis of spare proteins of the grain and is a relevant method for reliable identification of the target genotypes. A considerable advantage is even the fact that as little as $100 \mathrm{mg}$ of any tissue of the plant can be used as a sample for the analysis. The analysis of a leaf from a young plant can allow the scientist to predict whether its grain, which is still in the primordium, will be worth breeding.

Table 2. The biochemical characteristics and genetic control of the biosynthesis of barley hordeins (Shewry P, 1993; Gu Y et al, 2003)

\begin{tabular}{c|c|c|c|c|c}
\hline Hordeins & $\begin{array}{c}\text { \% from total } \\
\text { hordein }\end{array}$ & $\begin{array}{c}\text { Molecular mass, } \\
\mathrm{kDa}\end{array}$ & $\begin{array}{c}\text { Number of gene } \\
\text { copies }\end{array}$ & $\begin{array}{c}\text { Polymer } \\
\text { formation }\end{array}$ & Loci \\
\hline $\mathrm{B}$ & $70-80$ & $30-46$ & $13-50$ & Yes & Hor 2 \\
$\mathrm{C}$ & $10-20$ & $48-72$ & $20-30$ & No & Hor \\
$\mathrm{D}$ & $>5$ & $>100$ & 1 & Yes & Hor 3 \\
$\gamma$ & $>5$ & $38-45$ & $>5$ & Yes/No & Hor 5 \\
\hline
\end{tabular}




\section{CONCLUSIONS}

In the process of creating a hull-less, ultra-low gluten barley variety using international and Ukrainian breeding lines/cultivars we were successful already in the most crucial part of the study. This concerned obtaining a triple mutant genotype of food hull-free barley with ultra-low content of such gluten proteins as hordeins, containing all three mutations from genetic sources Risø1508, Risø56, and R118, which almost block the biosynthesis of barley hordeins and furthermore with black grain, originating from mutant R118, possessing bioactive pigments with high antioxidant activity. Hullfree genotypes with black grain and without D-hordein were selected by deficit mutation in locus Hor3 in the population from crossing mutant R118 and commercial variety Achilles. We identified the above-mentioned genotypes using protein electrophoretic and PCRbased methods. In this process a new protocol and new PCR primers to detect double mutations M56, M1508 and R118 which are associated with the accumulation of B, C and D hordeins in barley grains are described.

The genetic material, which has been used and obtained thus far, is based on spring mode of growth and development of barley only. However, hordein-deficient mutations Risø56 and Risø1508 have a considerable agronomic drawback - endosperm reduction, which is most likely to be related to decreased grain yield, due to involvement of a triple hordein-deficient genotype. Our future studies aim at transferring the obtained genetic foundation of target mutations onto the barley with winter mode of growth and development, in order to decrease the negative effect of hordein-deficient mutations on grain yield.

\section{ACKNOWLEDGMENTS}

We would like to express our sincere gratitude to staff of the international collections from USDA and Norwich for gently making available seeds of Risø56, Risø1508, R118, as well as the scientists from the Department of Genetic Foundations of Breeding, PBGINCSCI, - O.M. Blahodarova and A.V. Troianovska for assistance in conducting research.

Adherence to ethical principles. This article does not contain the results of any studies, involving humans and animals as study objects.

Conflict of interests. The authors deny any conflict of interests.

Financing. The financing was provided within the industry-sponsored topic of the NAS of Ukraine "The study of valuable genetic determinants and new allelic effects of genes to improve bread cereals under negative influence of global climatic changes", state registration number 0117U000385 and fundamental topic "Genetic and molecular-biological study of quality traits of grain from wheat, triticale, and hull-free barley as a prerequisite for creating the varieties of these crops for special technological use of grain" of the NAAS of Ukraine, NTP 2016-2020, state registration number $0116 \mathrm{U} 000679$.

\section{Створення голозерного ячменю \\ з ультранизьким вмістом глютену шляхом} комбінування цільових генів. І. Виділення потрійно мутантних чорнозерних генотипів

О. І. Рибалка ${ }^{1}$ В. Б. Катрій ${ }^{2}$,

С. С. Поліщук ${ }^{1}$, Б. В. Моргун ${ }^{3}$

${ }^{1}$ Національний центр насіннєзнавства

та сортовивчення «Селекційно-генетичний інститут» HAAH

вул. Овідіопольська дорога, 3, Одеса, Україна, 65036

${ }^{2}$ Інститут фізіології рослин і генетики НАН України вул. Васильківська, 31/17, Київ, Україна, 03022

${ }^{3}$ Інститут клітинної біології та генетичної інженерії НАН України вул. Академіка Заболотного, 148, Київ, Україна, 03143

E-mail: rybalkaalexander@gmail.com, katriy.vlad@gmail.com*, pol.sergey@ukr.net, molgen@icbge.org.ua

Мета. Створення селекційного матеріалу голозерного ячменю з ультранизьким вмістом у зерні глютену, який комбінує водночас три гордеїн-дефіцитні мутації від мутантних ліній ячменю Risø56 (В-гордеїни), Risø1508 (C-гордеїни) i R118 (D-гордеїни), та чорне зерно, як індикатор присутності у зерні біоактивних пігментів, що додають зерну, як харчовому продукту, функціонального статусу. Методи. У дослідженні використовували електрофоретичний аналіз білків у поліакриламідному гелі, виділення загальної ДНК, полімеразну ланцюгову реакцію з використанням маркерів B1hor, 3a5 та Dhor-m, рестрикцію та електрофоретичне розділення ДНК в агарозному гелі. Результати. Створення унікального харчового продукту з високим функціональним харчовим статусом (потрійно мутантного генотипу харчового голозерного ячменю з ультранизьким вмістом білків гордеїнів) $є$ кінцевим етапом дослідження. Подано результати першого етапу комбінування цільових гордеїн-дефіцитних мутацій шляхом бінарних схрещувань. Отримано i досліджено популяції $\mathrm{F}_{2 / 3}$ i $\mathrm{F}_{3 / 4}$ від схрещування мутантів Risø56 × Risø1508 (Risø1508 × Risø56) та R118 × $\times$ сорт голозерного ячменю Ахіллес. Оптимізовано новий протокол ПЛР. Маркери B1hor, 3a5 та Dhor-m були підібрані для ідентифікації му-тацій В-, С- та D-горденів. Висновки. За цільовими мутантними генами виділено декілька генотипів, що містять одну або 
дві мутації та ознаку чорна пігментація зернівки. Дослідження є першим в Україні, яке ставить завдання створення в недалекій перспективі сорту голозерного харчового ячменю з ультранизьким вмістом у зерні глютену. Отримані генотипи будуть використані у програмі бекросів для створення голозерного ячменю 3 ультранизьким вмістом у зерні глютену та чорним кольором зерна.

Ключові слова: Risø56, Risø1508, R118, глютен, молекулярні маркери.

\section{REFERENCES}

Aziz I, Lewis N, Hadjivassiliou M et al. (2014) A UK study assessing the population prevalence of self-reported gluten sensitivity and referral characteristics to secondary care. Eur. J. Gastroenterol. Hepatol. 26(1):33-39. doi: 10.1097/01.meg.0000435546.87251.f7.

Brennan C, Smith D, Harris $N$ et al. (1998) The production and characterisation of Hor 3 null lines of barley provides new information on the relationship of D hordein to malting performance. J. Cereal Sci. 28(3):291-299. doi: 10.1016/S0733-5210(98)90009-1.

Camerlengo F, Sestili F, Silvestri M et al. (2017) Production and molecular characterization of bread wheat lines with reduced amount of $\alpha$-type gliadins. BMC Plant Biol. 17(1):248-252. doi: 10.1186/s12870-017-1211-3.

Catassi C, Alaedini A, Bojarski C, et al. (2017) The overlapping area of non-coeliac gluten sensitivity (NCGS) and wheat-sensitive irritable bowel syndrome (IBS): An update. Nutrients. 9(11):1268. doi: 10.3390/nu 9111268.

Comino I, Real A, Moreno $M$ et al. (2013) Immunological determination of gliadin 33-mer equivalent peptides in beers as a specific and practical analytical method to assess safety for celiac patients. J. Sci. Food Agric. 93(4):933-943. doi: 10.1002/jsfa.5830.

Igbinedion S, Ansari J, Vasikaran A et al. (2017). Non-celiac gluten sensitivity: All wheat attack is not celiac. World J. Gastroenterol. 23(40):7201-7210. doi: 10.3748/wjg.v23. $\mathrm{i} 40.7201$.

Doll H, Oram R. (1989) Deviating Mendelian segregation of barley gene lys $3 a$. Brief report. Hereditas. 110:97-99. doi: 10.1111/j.1601-5223.1989.tb00426.x.

Fritz RD, Chen Y. (2017) Characterizing the distribution of ppm gluten in gluten free oatmeal servings Contaminated with a Wheat Kernel. J Food Res. 6(5):92-98. doi: $10.5539 /$ jfr.v6n5p92.

Gil-Humanes J, Pistón F, Altamirano-Fortoul $R$ et al. (2014) Reduced-gliadin wheat bread: an alternative to the glutenfree diet for consumers suffering glutenrelated pathologies. PLoS ONE. doi: 10.1371/journal. pone.0090898.

Gil-Humanes J, Pistón F, Tollefsen S et al. (2010) Effective shutdown in the expression of celiac disease-related wheat gliadin T-cell epitopes by RNA interference.
Proc. Natl. Acad. Sci. USA. 107(39):17023-17028. doi: 10.1073/pnas.1007773107.

Golley S, Corsini N, Topping D et al. (2015) Motivations for avoiding wheat consumption in Australia: results from a population survey. Public Health Nutr. 18(3):490-499. doi: $10.1017 /$ S1368980014000652.

Gu YQ, Anderson OD, Londeorë CF, Kong X et al. (2003) Structural organization of the barley D-hordein locus in comparison with its orthologous regions of wheat genomes. Genome. 46(6):1084-1097. doi: 10.1139/g03-071.

Kiewlicz J, Rybicka I. (2020) Minerals and their bioavailability in relation to dietary fiber, phytates and tannins from gluten and gluten-free flakes. Food Chem. 305:125452. doi: 10.1016/j.foodchem.2019.125452.

Kreis M, Shewry P, Forde B et al. (1983). Molecular analysis of a mutation conferring the high-lysine phenotype on the grain of barley (Hordeum vulgare). Cell. 34(1):161167. doi: 10.1016/0092-8674(83)90146-0.

Laemmli U. (1970) Cleavage of structural proteins during the assembly of the head of bacteriophage T4. Nature. 227(5259):680-685. doi: 10.1038/227680a0.

Moehs C, Austill W, Holm A et al. (2019) Development of decreased-gluten wheat enabled by determination of the genetic basis of lys 3 a barley. Plant. Physiol. 179(4):16921703. doi: 10.1104/pp.18.00771.

Ravikumara M, Nootigattu V, Sandhu B. (2007). Ninety percent of coeliac disease is being missed. J. Pediatr. Gastroenterol. Nutr. 45(4):497-499. doi: 10.1097/ MPG.0b013e31812e5710.

Rosell C, Sousa C, Barro F, et al. (2014) Cereals for developing gluten-free products and analytical tools for gluten detection.J.Cereal.Sci.59(3):354-364. doi: 10.1016/j.jcs. 2013.10.001.

Rybalka OI. (2010) Electrophoretic techniques for analysis of gluten proteins in wheat. Proc. PBGI-NCSCI. 16(56):166-174.

Rybalka OI, Morgun VV, Morgun BV, Polyshchuk SS. (2019) Genetic background for breeding of new quality classes of wheat (Triticum aestivum L.) and triticale ( $\times$ Triticosecale Wittmack). Fiziol. rast. genet. 51(3):207240. doi: $10.15407 / \mathrm{frg} 2019.03 .207$.

Sánchez-León S, Gil-Humanes J, Ozuna, C et al. (2018) Lowgluten, nontransgenic wheat engineered with CRISPR/ Cas9. Plant Biotechnol. J. 16(4):902-910. doi: 10.1111/ pbi.12837.

Scherf KA, Wieser H, Koehler P. (2018) Novel approaches for enzymatic gluten degradation to create high-quality gluten-free products. Food Res Int. J. 110:62-72. doi: 10.1016/j.foodres.2016.11.021.

Schalk K, Lexhaller B, Koehler P et al. (2017) Isolation and characterization of gluten protein types from wheat, rye, barley and oats for use as reference materials. Plos One. 12(2):e0172819. doi: 10.1371/journal.pone.0172819.

Singh P, Arora A, Strand T, et al. (2018). Global prevalence of celiac disease: systematic review and meta-analysis. 


\section{DEVELOPMENT OF HULL-LESS BARLEY WITH ULTRA-LOW GLUTEN CONTENT}

Clin. Gastroenterol. Hepatol. 16(6):823-836.e2. doi: 10. 1016/j.cgh.2017.06.037.

Shewry PR. (1993) Barley Seed Proteins, in: Barley: Chemistry and Technology (eds. J. MacGregor and R. Bhatty). AACC, St. Paul Minnesota, USA, p. 131-197.

Shewry P, Bunce N, Kreis $M$ et al. (1985) Polymorphism at the Hor 1 locus of barley (Hordeum vulgare L.). Biochem Genet. 23(5-6):391-404. doi: 10.1007/BF00499082.

Sozinov A, Netsvetaev V, Poperelja F, Navolotsky V. (1976) Resto-ration of the locus Pr-a activity and its dosage effect in hybrids of barley (Hordeum vulgare L). Genetica. 12(10):55-59. (in Russian)

Strygina K, Khlestkina E. (2020) Wheat, barley and maize genes editing using the CRISPR/Cas system. Plant Biotechnol. Breed. 3(1):46-56. (In Russian) doi: 10.30901/ 2658-6266-2020-1-02.

Tanner G, Blundell M, Colgrave $M$ et al. (2016) Creation of the first ultra-low gluten barley (Hordeum vulgare L.) for coeliac and gluten-intolerant populations. Plant Biotechnol J. 14(4):1139-1150. doi: 10.111/pbi.12482.

Tanner G, Blundell M, Colgrave M, et al. (2013) Quantification of hordeins by ELISA: The correct standard makes a magnitude of difference. PLoS one. 8(2): e56456. doi: 10.1371/journal.pone.0056456.

Tanner G, Colgrave M, Blundell M, Howitt CA, Bacic A. (2019) Hordein accumulation in developing barley grains. Front Plant Sci. 10:649. doi: 10.3389/fpls. 2019.00649.

Tanner G, Howitt C, Colgrave $M$ et al. (2014) European Patent Office EP3008161A1.

Zuidmeer L, Goldhahn K, Rona R et al. (2008) The prevalence of plant food allergies: a systematic review. J. Allergy Clin Immunol. 121(5):1210-1218.e4. doi: 10. 1016/j.jaci.2008.02.019. 